\title{
Neurotoxins in the polar fraction of the seaweed Galaxaura marginata (Rhodophyta, Nemaliales)
}

\author{
Enrique E. Rozas, * José C. Freitas \\ Departamento de Fisiologia, Instituto de Biociências, Universidade de São Paulo, Rua do Matão, Travessa 14, \\ no.101, 05508-900 São Paulo-SP, Brasil
}

\begin{abstract}
RESUMO: "Neurotoxinas na fração polar da alga marinha Galaxaura marginata (Rhodophyta, Nemaliales)". A atividade neurotóxica das substâncias polares extraídas da alga vermelha Galaxaura marginata foi estudada por meio de ensaios farmacológicos, utilizando-se

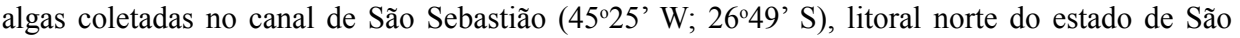
Paulo, Brasil. Altas concentrações da fração polar (PF) e da PF filtrada em membrana de 1000 $\mathrm{Da}$, injetadas intraperitonealmente em camundongos, foram letais. Induzindo os animais à ataxia, desorientação e severa atonia muscular prévias à morte. Sintomas similares foram descritos para camundongos e ratos testados com aminoácidos neuroexcitatórios (NEA), sugerindo que alguns dos componentes da PF atravessam a barreira Hematoencefálica, da mesma forma que os NEA. No entanto, a análise da PF no HPLC e no espectro de massa não mostraram a presença dos aminoácidos neuroexcitatórios conhecidos, ácido Caínico, acido Domóico e NMDA. Assim concluímos que G. marginata possui substâncias com atividade letal e neurotóxica, diferentes às antes, descritas.
\end{abstract}

Unitermos: Galaxaura marginata, neurotóxico, neuroexcitatório, alga.

\begin{abstract}
Neurotoxic activity of polar substances extracted from the red seaweed Galaxaura marginata was investigated in pharmacological assays, using seaweed collected at São Sebastião

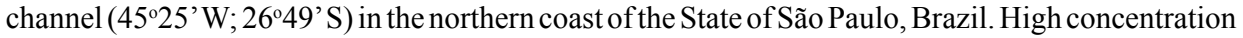
of the polar fraction (PF) and PF filtered through a membrane (1000 Da) intraperitoneally (IP) injected in mice were lethal, inducing ataxia, disorientation, and severe muscle atonia prior to death. The same symptoms preceding death were described in mice and rat tested with neuroexcitatory amino acids (NEA), suggesting that some PF components cross the blood-brain barrier, the same as NEA. However, the HPLC and mass spectrometric analysis did not show the presence of the known neuroexcitatory amino acids, kainic acid, domoic acid and NMDA. We conclude that G. marginata possess substances with neurotoxic and lethal activities.
\end{abstract}

Keywords: Galaxaura marginata, neurotoxic, neuroexcitatory, seaweed.

\section{INTRODUCTION}

The neuroexcitatory substances domoic acid (DA), kainic acid (KA) and $N$-methyl-D-aspartic (NMDA) were determined in the red seaweeds collected in the islands of Japan (i. e. NMDA/ DA in Amansia glomerata J. Agardh and NMDA/ KA in Laurencia papilosa (C.Agardh) (Greville) (Sato et al., 1996). The presence of glutamate in Liagora disjunta Lamouroux (Nemaliales, Rhodophyta), another amino acid which activates neurons in the central nervous system of mammals (Impellizzeri et al., 1975), was also determined. These neurotoxic substances activate glutamatergic receptors in several areas of the brain, regulating neuronal excitability and synaptic transmission (Bianchin et al., 2000; Kalda et al., 2000; Rozas \& Freitas, 2008) and cause death in high concentration (Doucette et al., 2000). DA is an amino acid with a structure similar to KA. However little is known about the mechanisms of its neurotoxicity. There is some evidence that DA interferes in the absorption of extracellular glutamate (Nagatomo et al., 1999). Glutamate is the major excitatory neurotransmitter acting at a variety of excitatory synapses with its own receptors in the brain. Glutamate action is due to a rapid membrane depolarization induced by an influx of $\mathrm{Na}^{+}$and, in some cases $\mathrm{Ca}^{+}$(Ross et al., 2000; Nishizawa, 2001). NMDA have its own receptors but the fulfillment is coupled to glutamatergic receptor activated by KA, DA, glutamate, glutamine and others amino acid, what determine the influx or out flux of ions post- or pre-synaptically (Nishizawa, 2001). Early pharmacological screening with seaweeds collected in Brazilian coast (Freitas \& Marsiglio, 1986) demonstrated that methanol extracts of G. marginata J.V. Lamouroux, in high concentrations, induced negative inotropy and cronotropy in toad hearts as well as depression of muscle twitches elicited by electrical stimulation of the phrenic nerve in mouse neuromuscular preparations. The purposes of this study were to evaluate the neurotoxic activity of G. marginata extracts and improve methods to determine the active substance. 


\section{MATERIAL AND METHODS}

\section{Preparation of extracts}

To obtain the extract, a sample of $G$. marginata $(1 \mathrm{~kg})$ was collected by free diving in shallow waters of São Sebastião channel $\left(45^{\circ} 25^{\prime} \mathrm{W}\right.$; 26 $\left.6^{\circ} 49^{\prime} \mathrm{S}\right)$, northern coast of the State of São Paulo, Brazil, during the spring of 2000. The algae were washed with fresh water to remove epiphytes and salts. The samples were homogenized in a blender with ethanol: acetic acid $(5: 1 \mathrm{v} / \mathrm{v})$ and filtered through a Whatman $\mathrm{N}^{\circ} 41$ paper filter (Whatman Ltd; England). The mixture was concentrated under reduced pressure in a rotary evaporator (Büchi, Switzerland) until the solvents were eliminated and partitioned with hexane two fold, to withdraw the apolar substances (Sheu et al., 1996). The polar fraction obtained from this partition was filtered through a membrane of $1 \mathrm{KDa}$ cut off (Diaflo ${ }^{\circledR}$, Amicon, Inc., USA) under $4.5 \mathrm{~kg} / \mathrm{cm}^{2}$ nitrogen pressure, lyophilized and kept at $-20{ }^{\circ} \mathrm{C}$ until tested. This filtrated (PFM) $(200 \mathrm{mg} / \mathrm{mL})$ was loaded in a column (3.4 x $1.5 \mathrm{~cm}$ i.d.) of Amberlite IRA-400 AR strongly basic (Rohm and Haas Co, USA), the column was washed with $80 \mathrm{~mL}$ of water and then eluted with $80 \mathrm{~mL}$ of acetic acid $2 \mathrm{~N}$ to recover anionic fraction (AF) (Sato et al., 1996).
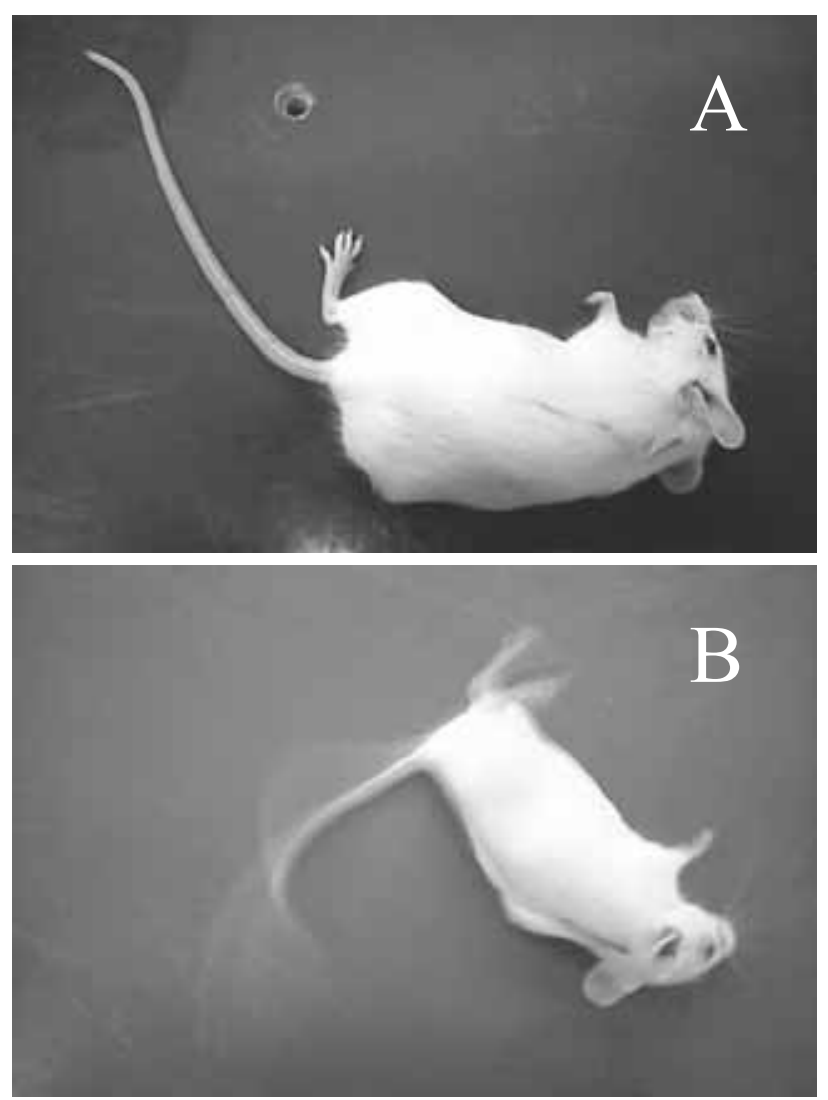

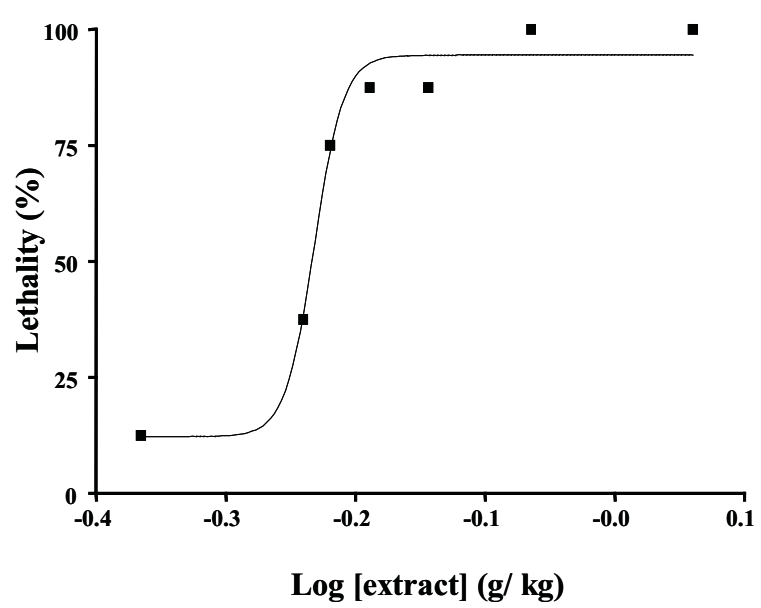

Figure 1. The curve represent the lethal activity induced by the polar fraction (PF) obtained from the red seaweed Galaxaura marginata $\left(\mathrm{LD}_{50}: 0.59 \mathrm{~g} / \mathrm{kg}, \mathrm{CI}_{95 \%}: 0.57\right.$ to $0.60 \mathrm{~g} / \mathrm{kg}$ ), when injected in mice $(\mathrm{n}=8)$.

\section{Neurotoxicity assay}

Swiss albino mice (Mus musculus) $(17.4 \pm 0.9$ g) were injected IP with apolar, polar and PFM fractions, each dissolved in Krebs-Henseleit (K-H) solution
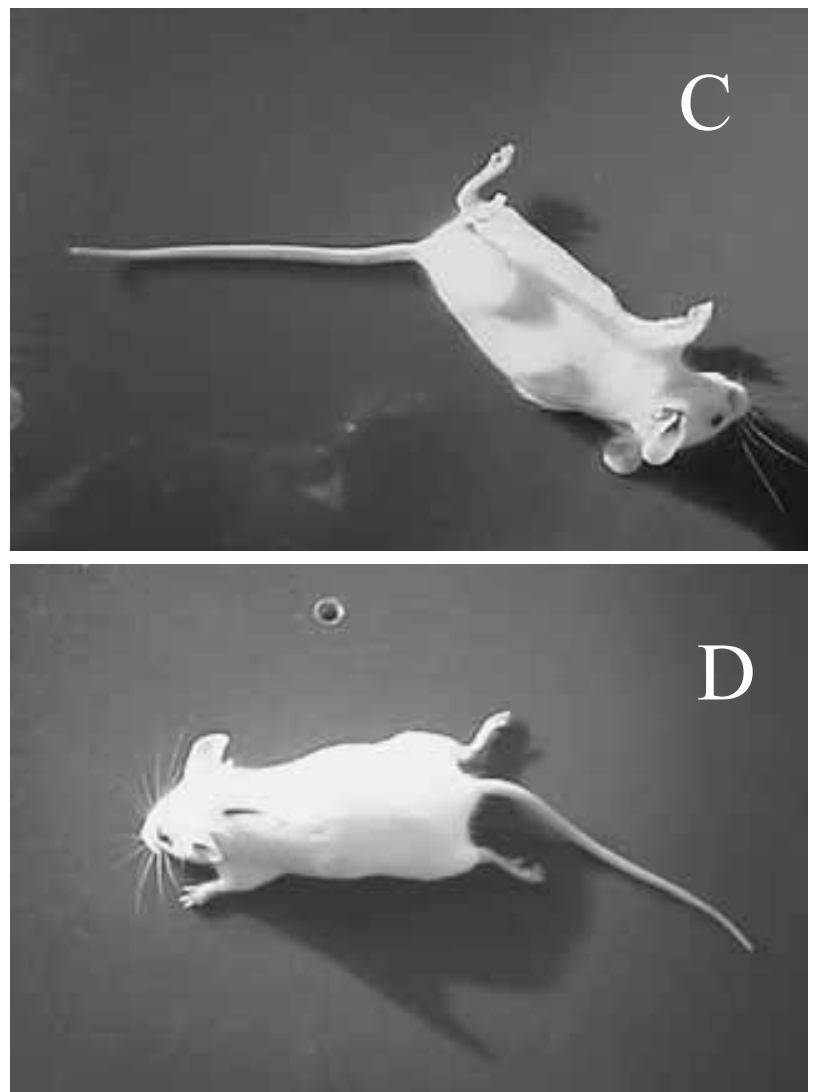

Figure 2. The images show the different postures induced by the PF injected in mice, consecutively exhibited tetanic posture (A), rotational behavior (B), epileptic display (C) and a cataleptic stage (E), prior to death. 

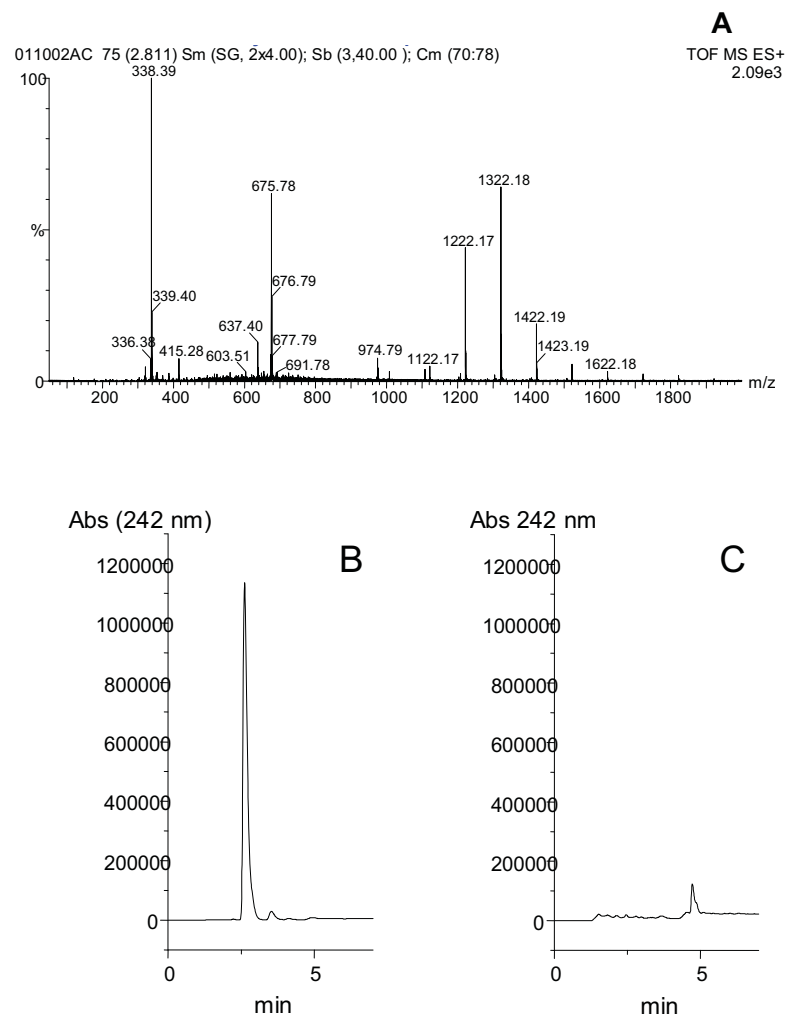

Figure 3. Mass spectral (A) and HPLC-UV analysis profile of standard domoic acid (B) and unknown sample (C). To HPLC analysis 20 of anionic fraction and $5 \mu \mathrm{g}$ of DA were chromatographed on a C-18 column, eluted with $0,1 \%$ acid trifluoroacetic in $10 \%$ aqueous acetonitrile as a mobile phase for $23 \mathrm{~min}$ in an isocratic gradient.

(Rangel et al., 1997, the mice $(\mathrm{n}=8)$ received $0.5 \mathrm{~mL}$ $(0.4$ to $1.7 \mathrm{~g} / \mathrm{kg})$ of apolar and polar extract. To facilitate the dilution of the apolar extracts, each milligram was diluted in $5 \mu \mathrm{L}$ of dimethyl sulfoxide (DMSO) prior to addition of K-H solution. Controls were carried out using K-H solution, and DMSO in the same volumes used in the assay $(n=8)$. Lethal activity was evaluated quantitatively by determination of Lethal dose $\left(\mathrm{LD}_{50}\right)$ (Ipsen \& Feigl, 1970).

\section{Domoic acid detection}

The analysis was prepared in LC-10A HPLC system (Shimadzu, Japan). $5 \mu \mathrm{g}$ of DA (Sigma) and $20 \mu \mathrm{g}$ of AF were chromatographed on a C-18 column ( $250 \times 4.6 \mathrm{~mm}, 5 \mu \mathrm{M}$, ODS Hypersil, Supelco, Sigma), eluted with $0,1 \%$ acid trifluoroacetic in $10 \%$ aqueous acetonitrile as a mobile phase for $23 \mathrm{~min}$ in an isocratic gradient. The temperature was kept at $40{ }^{\circ} \mathrm{C}$, the flow rate at $1.2 \mathrm{~mL} / \mathrm{min}$, and the substances eluted from the column were monitored at $242 \mathrm{~nm}$ (Zaman et al., 1997).
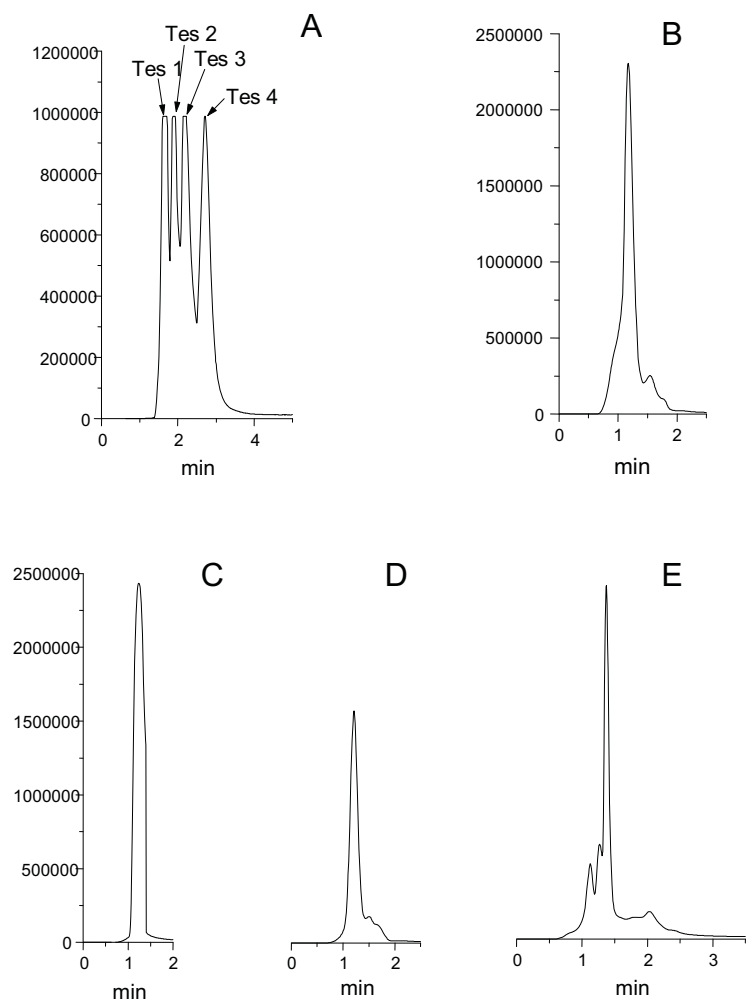

Figure 4. Elution profile of the Anionic fraction (AF) of Galaxaura marginata in HPLC analysis (A). AF was eluted with acetonitrile and water in a linear solvent gradient from $0-100 \%$, $100 \%$, and $100-0 \%$ acetonitrile. B, C and D showed the profile of each peak of AF cromatographed separately. The temperature was kept at $40^{\circ} \mathrm{C}$, the flow rate at $2 \mathrm{~mL} / \mathrm{min}$, and the substances eluted from the column were monitored at $200 \mathrm{~nm}$.

\section{Purification of substances present in the AF}

After determining the maximum absorbance in a $\mathrm{DU}^{\circledR}-70$ Spectrophotometer (Beckman, USA), 200 $\mu \mathrm{g}$ of AF were injected in the LC-10A HPLC system (Shimadzu, Japan). The substances were eluted in the C-18 column ( $250 \times 4,6 \mathrm{~mm}, 5 \mu$, ODS Hypersil, Supelco, Sigma), with acetonitrile (A) and water (B) in a linear solvent gradient from $0-100 \% \mathrm{~A}$, between 0 and $7 \mathrm{~min}, 100 \% \mathrm{~A}$, between 7 and $10 \mathrm{~min}$, and $100-0 \%$, between 10 and $22 \mathrm{~min}$. The temperature was kept at 40 ${ }^{\circ} \mathrm{C}$, the flow rate at $2 \mathrm{~mL} / \mathrm{min}$, and the substances eluted from the column were monitored at $200 \mathrm{~nm}$. The peak fractions were collected, lyophilized, and kept at $-20^{\circ} \mathrm{C}$ until analysis.

\section{Mass spectral analysis}

A portion of $\mathrm{PF}$ and each peak fraction obtained from the HPLC system were dissolved in small amount of $50 \%$ aqueous methanol, and electrospray ionization mass spectra was taken using a Q-TOF mass spectrometer (Micromass, U.K.). 


\section{RESULTS}

The polar fraction $(\mathrm{PF})$ and $\mathrm{PF}$ filtered to 1 $\mathrm{KDa}$ membrane induced the death of the mice, whereas the apolar fraction was not active in this procedure. The PF showed the lethal activity $105 \mathrm{~min}$. after injected, causing the death of the mice with a $\mathrm{LD}_{50}$ of $0.59 \mathrm{~g} / \mathrm{kg}$ $\left(\mathrm{CI}_{95 \%}: 0.57\right.$ to $0.60 \mathrm{~g} / \mathrm{kg}$ ) (Figure 1). The mice injected with PF, showed tetanic posture (Figure 2, A), rotational behavior, (Figure 2, B) epileptic display (Figure 2, C), and a cataleptic stage (Figure 2, D), consecutively prior to death. The HPLC and mass spectral analysis (Figure 3) did not show the presence of DA or KA in samples of G. marginata. However, the HPLC analysis showed the presence of four peaks with unique absorption at 200 nm (Figure 4, A). Each peak, after new chromatography procedure (Figure 4, B, C and D) was analyzed in a mass spectrometer, but the response was undistinguishable from the basal noise.

\section{DISCUSSION}

Extracts and structurally diverse compounds obtained from marine red algae have been shown to exhibit neurotoxic activity in rodents (Freitas \& Marsiglio, 1986; Impellizzeri et al., 1975). In the present work, we extend these findings by reporting that red marine algae G. marginata possess a neurotoxic polar fraction. Mice IP injected with the polar fraction showed prior to death symptoms similar to those exhibited by mice that were injected with KA, which consist of tetanic, rotational (Rimbau et al., 1999), convulsive (Giovengo et al., 1999), and cataleptic behaviors (Bhakuni \& Silva, 1974). This suggests that the polar fraction crosses the blood-brain barrier in the same way as KA or DA. Kainic (KA) and domoic (DA) acids are known as potent neuroexcitotoxins isolated from red algae (Ceccon et al., 2000; Sato et al., 1996; Tucci et al., 2000), which are able to cross the blood-brain barrier, activating glutamatergic systems in several brain areas and affecting social interactions (Tucci et al., 2000). This activation, when elicited at maximal concentration of KA or DA results in widespread neuronal damage throughout the brain of the mouse (Nagatomo et al., 1999). However, HPLC analysis showed the absence of the neuroexcitatory amino acid (NAA) DA, and the mass spectral analysis confirms the absence of DA and KA, the only NAAs reported in the family Rhodomelaceae (Sato et al.,1996). These results showed that the lethal activity in mice was produced by neurotoxic substances other than NAAs. In the course of searching for the active substance, the HPLC analysis $(200 \mathrm{~nm})$ showed the presence of four peaks in the anionic fraction of polar extract. However mass spectral analysis did not exhibit peaks distinguishable from the basal noise, owing to not be possible the ionization of the active substances.

\section{ACKNOWLEDGMENTS}

This work was supported by grant from $\mathrm{CNPq}$ and FAPESP. The author is grateful to Dr. Katsuhiro Konno of the Center of Applied Toxinology (SP-Brazil) for the mass spectral analysis.

\section{REFERENCES}

Bhakuni D, Silva M 1974. Biodinamic substances from marine flora. Bot Mar 27: 40-51.

Bianchin M, Spanios M, Roesler C, McGaugh R, Izquierdo I 2000. ( \pm )- $\propto$-Methyl-4-carboxyphenylglycine, a metabotropic glutamate receptor blocker, impairs retention of an inhibitory avoidance task in rats when infused into the basolateral nucleus of the amygdala. Brain Res 852: 436-443.

Ceccon M, Giusti P, Facci L, Borin G, Imbesi M, Floreani M, Skaper S 2000. Intracellular glutathione levels determine cerebellar granule neuron sensitivity to excitotoxic injury by kainic acid. Brain Res 862 : 83-89.

Doucette T, Strain S, Allen G, Ryan C, Tasker R 2000. Comparative behavioral toxicity of domoic acid and kainic acid in neonatal rat. Neurotoxicol Teratol 22: 863-869.

Freitas JC, Marsiglio A 1986. Pharmacological activity of extract of some marine algae from the brazilian coast. Bolm Fisiol Anim Univ S Paulo 10: 61-68

Giovengo S, Kitto K, Kurtz H, Velazquéz R, Larson A 1999. Parenterally administered kainic acid induces a persistent hyperalgesia in the mouse and rat. Pain 83: 347-358.

Impellizzeri G, Mangiafico S, Oriente G, Piattelli M, Sciuto S 1975. Amino acids and low-molecular weight carbohydrates of some marine red algae. Phytochemistry 14: 1549-1557.

Ipsen J, Feigl P 1970. Bioassay. In: Brancroft's introduction to biosestatistic. Harper and Row, New YorK. USA. p. 163-170.

Kalda A, Kaasik A, Vassiljev V, Pokk P, Zharkovsky A 2000. Neuroprotective action of group I metabotropic glutamate receptor agonists against oxygen-glucose deprivation-induced neuronal death. Brain Res 853 : 370-373.

Nagatomo I, Akasaki Y, Ushida M, Tominaga M, Kuchiiwa S, Nakagawa S, Takigawa M 1999. Kainic and domoic acids differentially affect NADPH-diaphorase neurons in the mouse hippocampal formation. Brain Res Bull 48: 277-282.

Nishizawa Y 2001. Glutamate release and neuronal damage in ischemia. Life Sci 69: 369-381.

Rangel M, Malpezzi E, Susini S, Freitas JC 1997. Hemolytic activity in extracts of the diatom Nitzschia. Toxicon 35: 305-309.

Rimbau V, Camins A, Romay C, González R, Pallàs M 1999. Protective effects of $\mathrm{C}$-phycocyanin against kainic acid-induced neuronal damage in rat hippocampus. Neurosci Lett 276: 75-78.

Ross I, Johnson W, Sapienza P, Kim C 2000. Effects of the seafood toxin domoic acid on glutamate uptake by rat astrocytes. Food Chem Toxicol 38: 1005-1011. 
Rozas EE, Freitas JC 2008. Intracellular increase of glutamate in neuroblatoma cells induced by polar substances of Galaxaura marginata (Rhodophyta, Nemaliales). Rev Bras Farmacogn 18: 53-62.

Sato M, Nakano T, Takeuchi M, Kanno N, Nagahisae E, Sato Y 1996. Distribution of neuroexcitatory amino acids in marine algae. Phytochemistry 42: 1595-1597.

Sheu J, Huang S, Duh C 1996. Cytotoxic oxigenated desmosterols of the red alga Galaxaura marginata. J Nat Prod 59: 23-26.

Tucci S, Contreras Q, Paez X, González L, Rada P, Hernandez L 2000. Medial prefrontal transection enhances social interaction II: Neurochemical studies. Brain Res 887: 259-265.

Zaman L, Arakawa O, Shimosu A, Onoue Y, Nishi S, Shida Y, Noguchi T 1997. Two new isomers of domoic acid from a red alga, Chondria armata. Toxicon 35: 205-212. 